\title{
Oxidation and Complexation-Based Spectrophotometric Methods for Sensitive Determination of Tartrazine E102 in Some Commercial Food Samples
}

\author{
Magda M. S. Saleh*, Elham Y. Hashem, Najat O. A. Al-Salahi \\ Chemistry Department, Faculty of Science, Assiut University, Assiut, Egypt \\ Email: "magdamssaleh@yahoo.com
}

Received 6 March 2016; accepted 25 April 2016; published 28 April 2016

Copyright @ 2016 by authors and Scientific Research Publishing Inc.

This work is licensed under the Creative Commons Attribution International License (CC BY). http://creativecommons.org/licenses/by/4.0/

cc) (i) Open Access

\section{Abstract}

Two new sensitive spectrophotometric methods are reported for determination of tartrazine (Tz) (E102) in some commercial food samples. The first method involves two coupled reactions, the reduction of $\mathrm{Cu}(\mathrm{II})$ to $\mathrm{Cu}(\mathrm{I})$ by the analyte in acetate buffer medium $(\mathrm{pH}=5.9)$ at $30^{\circ} \mathrm{C}$ and the complexation reaction between $\mathrm{Cu}(\mathrm{I})$ and $\mathrm{Tz}$ oxidized form to yield $\mathrm{Cu}$-Tz complex (method I). The other method is based on oxidation of $\mathrm{Tz}$ by alkaline $\mathrm{KMnO}_{4}$. These reactions are monitored spectrophotometrically at maximum absorbances 332 and $610 \mathrm{~nm}$ for methods (I and II) respectively. Variables affecting these reactions are carefully studied and the conditions are optimized. The stability constants are calculated at $293,303,313$ and $323 \mathrm{~K}$. The thermodynamic parameters, Gibb's free energy change $(\Delta G)$, entropy change $(\Delta S)$, and enthalpy change $(\Delta H)$ associated with the complexation reaction are calculated and discussed. Under optimized conditions the proposed methods (I, II) obey Beer's law 10.69 - 85.50, 5.34 - $34.12 \mu \mathrm{g} \cdot \mathrm{ml}^{-1}$ of $\mathrm{Tz}$ respectively. The molar absorptivity, sandel sensitivity, detection and quantification limits are calculated. Matrix effects are also investigated. The methods are successfully applied to the quantification of $\mathrm{Tz}$ in different commercially food samples. The results obtained are in good agreement with those obtained by the reported methods at the $\mathbf{9 5 \%}$ confidence level.

\section{Keywords}

Tartrazine E102, Food Colorants, Complexation, $\mathrm{KMnO}_{4}$, Spectrophotometric Analysis

\footnotetext{
${ }^{*}$ Corresponding author.
}

How to cite this paper: Saleh, M.M.S., Hashem, E.Y. and AI-Salahi, N.O.A. (2016) Oxidation and Complexation-Based Spectrophotometric Methods for Sensitive Determination of Tartrazine E102 in Some Commercial Food Samples. Computational Chemistry, 4, 51-64. http://dx.doi.org/10.4236/cc.2016.42005 


\section{Introduction}

Food dyes are often added to foodstuffs and drinks in order to supply, intensify or restore their colour to create the desired coloured appearance [1]. Synthetic dyes are widely used as they show several advantages compared with natural dyes such as high stability to light, oxygen and $\mathrm{pH}$, colour uniformity, low microbiological contamination and relatively lower production costs. Tartrazine is a synthetic organic food dye that can be found in common food products such as bakery products, dairy products, candies, and beverages. According to the limitations of European Union [EU] and Federal Food, Drug and Cosmetic Act [2], the presence and content of Tz dye must be controlled in food products due to their potential harmfulness to human beings [3]. Also it appears to cause the most allergic and intolerance reaction of all the azo dyes, particularly among asthmatics and those with an aspirin intolerance [4] [5]. Therefore the determination of tartrazine in commercial food products is very important. Until now, different methods such as chromatography [6]-[12], electroanalytical methods [13]-[15] and spectrophotometry [16]-[24], have been reported for the determination of tartrazine. However, some of these methods are not suitable for routine monitoring as they are time consuming, complicated and have poor sensitivity and selectivity. To the best of our knowledge, no spectrophotometer methods based on complexation with copper have been reported for the quantification of Tz. This paper describes the development of a simple, and rapid two spectrophotometric methods for the assay of Tz in food samples. The first method is based on oxidation of tartrazine by $\mathrm{Cu}(\mathrm{II})$ in acetate-acetic acid medium $(\mathrm{pH}=5.9)$ at $30^{\circ} \mathrm{C}$ followed by complex formation. The other method is based on oxidation of $\mathrm{Tz}$ with alkaline $\mathrm{KMnO}_{4}$ under optimum conditions.

\section{Experimental}

\subsection{Apparatus}

An evolution 300 UV-Vis spectrophotometer with $1.0 \mathrm{~cm}$ matched cells fitted with vision pro software of Thermo Electronic Corporation (Cambridge, U.K.) was used for electronic spectral measurements. pH measurements were made with Jenway 3040 ion analyzer-pH meter, equipped with Jenway 924,005 combined glass electrode.

\subsection{Chemicals}

All chemicals were of analytical reagent grade. Deionized water was used to prepare all solutions. The tartrazine dye (E102) was supplied from Alfa Aesar (Germany). Stock standard solution containing $2.672 \mathrm{~g} \cdot \mathrm{L}^{-1}$ of the dye was prepared in deionized water. The working solutions were prepared daily by appropriate dilution. A $5 \times 10^{-3}$ $\mathrm{mol} \cdot \mathrm{L}^{-1}$ of copper nitrate was prepared by dissolving the required amount in deionized water and standardized complexmetrically with EDTA [25]. The ionic strength of the solutions was maintained at a constant value of $\mathrm{I}=$ $0.1 \mathrm{~mol} \cdot \mathrm{L}^{-1}\left(\mathrm{NaClO}_{4}\right)$. Acetic acid $\left(0.2 \mathrm{~mol} \cdot \mathrm{L}^{-1}\right)$ sodium acetate $\left(0.2 \mathrm{~mol} \cdot \mathrm{L}^{-1}\right)$ buffer $(\mathrm{pH}=5.9)$ was prepared in $100 \mathrm{ml}$ volumetric flask. Potassium permanganate (Merck, Germany) $1 \times 10^{-2} \mathrm{~mol} \cdot \mathrm{L}^{-1}$ was prepared in deionized water.

\subsection{Preparation of Real Samples}

Powdered gelatin samples (Lemon, pineapple, green apple, apricot, banana and peach) and powdered drinks (apple, orange and tamarind) were bought from local supermarket in Assiut city (Egypt). These samples contained sugars, fumaric and citric acids, beef gelatin, artificial flavour, colour (E102), tricalcium phosphate and aspartame. Each gelatin or drink samples were weighed exactly (about $1 \mathrm{~g}$ ) and dissolved in $50 \mathrm{ml}$ of deionized water. Then each solution was centrifuged $(10 \mathrm{~min}, 3500 \mathrm{rpm})$ to remove the insoluble particles. The filtrate was collected in $100 \mathrm{ml}$ volumetric flask and diluted to the mark with deionized water. For determination of $\mathrm{Tz}$ in the above real samples, $0.2 \mathrm{ml}$ of sample solution was used and analyzed according to method I. Finally, the Tz content in food samples were determined using the calibration equation and standard addition calibration curves procedure.

\subsection{General Procedures}

\subsubsection{Method I (Complexation Reaction)}

Into a $10 \mathrm{ml}$ volumetric flasks, transfer a suitable aliquot of standard solution in deionized water containing up 
to $181.6 \mu \mathrm{g}$ of tartrazine and $4 \mathrm{ml}$ of $2 \times 10^{-3} \mathrm{~mol} \cdot \mathrm{L}^{-1}$ of $\mathrm{Cu}(\mathrm{II})$ solution. After mixing, the mixture was buffered to $\mathrm{pH} 5.9$ with acetic acid-acetate buffer. Dilute the resulting solution to volume with deionized water and measure the absorbance at $332 \mathrm{~nm}, 303 \mathrm{~K}$ by using $1.0 \mathrm{~cm}$ quartz cell against a similarly prepared blank of the same $\mathrm{pH}$. The calibration graph was constructed by plotting absorbance vs. Tz concentration.

\subsubsection{Method II (Oxidation with $\mathrm{KMnO}_{4}$ )}

Standard solutions in deionized water containing $16.031-187.03 \mu \mathrm{g} \cdot \mathrm{ml}^{-1} \mathrm{Tz}$ were transferred into individual 10 $\mathrm{ml}$ calibrated flasks, $4.0 \mathrm{ml}$ of $1.0 \mathrm{~mol} \cdot \mathrm{L}^{-1}$ sodium hydroxide solution was added followed by $2.0 \mathrm{ml}$ of $1 \times 10^{-2}$ $\mathrm{mol} \cdot \mathrm{L}^{-1} \mathrm{KMnO}_{4}$ solution and it was diluted to the final volume with deionized water. After $60 \mathrm{~min}$, the absorbance was measured at $610 \mathrm{~nm}$ against reagent blank treated similarly.

\subsection{Interference from Matrix}

Samples were prepared by mixing $0.5344 \mathrm{mg}$ of $\mathrm{Tz}$ (method I) or $0.267 \mathrm{mg}$ (in case of method II) with various amounts of common matrix cations, anions, sugar, gelatin, aspartame and dyes such as sunset yellow, and allura red. The procedure was continued as described under general procedures.

\subsection{Determination of the Thermodynamic Parameters}

The decomposition of stability constant into its enthalpy change $(\Delta H)$, Gibbs free energy change $(\Delta G)$ and entropic $(\Delta S)$ contributions is of fundamental importance to understand the various factors that may influence coordination [26] [27]. Enthalpy changes due to coordination reactions can always be obtained from the determination of stability constants at different temperatures according to the Van't Hoff [28] relationship $(1,2)$ :

$$
\begin{gathered}
\Delta G=-2.303 R T \log K_{i}=\Delta H-T \triangle S \\
\log K_{i}=\left(\frac{-\Delta H}{2.303 R}\right) \frac{1}{T}+\frac{\Delta S}{2.303 R}
\end{gathered}
$$

where $R$ is ideal gas constant $\left(8.314 \mathrm{JK}^{-1} \cdot \mathrm{mol}^{-1}\right), K_{i}$ is the stability constant of the complex and $T$ is the absolute temperature in Kelvin $(K)$.

\section{Results and Discussion}

\subsection{Acid-Base Equilibria of Tartrazine}

The absorption spectra of tartrazine salt $\left(\mathrm{HL}^{3-}\right)$ solution $\left(5 \times 10^{-5} \mathrm{mo} \cdot \mathrm{L}^{-1}\right)$ in aqueous medium at $I=0.1 \mathrm{~mol} \cdot \mathrm{L}^{-1}$ $\left(\mathrm{NaClO}_{4}\right), 25^{\circ} \mathrm{C}$ were recorded at various $\mathrm{pH}$ values (Figure 1). The food additive tartrazine salt $\left(\mathrm{HL}^{3-}\right.$ ) yields four acid-base forms in solution of $\mathrm{pH} 0.86-12.4, \mathrm{H}_{5} \mathrm{~L}^{+}, \mathrm{H}_{2} \mathrm{~L}^{2-}$, $\mathrm{HL}^{3-}$ and $\mathrm{L}^{4-}$ exhibiting the absorption maxima at 440, 430, 420 and $400 \mathrm{~nm}$. The protonated acid form $\mathrm{H}_{5} \mathrm{~L}^{+}$at azo-nitrogen $\left(\lambda_{\max }=440 \mathrm{~nm}\right)$ predominates in strongly acidic medium $(\mathrm{pH}<3)$. The solution spectra of food colorant display a symmetrical and highly intense band $\left(\lambda_{\max }=430 \mathrm{~nm}\right)$ at $\mathrm{pH} 3.2-4.3$ corresponding to the protonated form of the dye salt $\left(\mathrm{H}_{2} \mathrm{~L}^{2-}\right)$. On decreasing, the acidity of the medium (4.2 - 6.5), a blue shift of the latter band at $420 \mathrm{~nm}$ is obtained resulting from dissociation of protonated nitrogen azo group $\left(\mathrm{HL}^{3-}\right)$. The electronic spectra of $\mathrm{Tz}$ in aqueous medium within $\mathrm{pH} 7.2$ - 10.4 exhibit a broad band at $400 \mathrm{~nm}$ with a shoulder at $425 \mathrm{~nm}$ corresponding to tautomeric equilibria of monoanionic form of tartrazine salt $\left(\mathrm{L}^{4-}\right)$, Scheme 1. The absorbance versus $\mathrm{pH}$ graph were interpreted [29] assuming that a particular equilibrium established under selected conditions. Under our experimental condition $\mathrm{pKa}_{1}\left[\mathrm{H}_{2} \mathrm{~L}^{-2} / \mathrm{HL}^{-3}(-\mathrm{HN}=\mathrm{N}-)\right]=5.15 \pm 0.10, \mathrm{pKa}_{2}\left[\mathrm{HL}^{-3} / \mathrm{L}^{-4}(\mathrm{OH})\right]=9.25 \pm 0.16$.

\subsection{Absorption Spectra of Tartrazine Reaction Products}

Tartrazine likes Sudan dyes possess two reducible groups, a nitrogen-nitrogen double bond and a phenol group [30]. A reduction process, which corresponds to a spontaneous auto-reduction of the $\mathrm{Cu}^{2+}$ into $\mathrm{Cu}^{+}$, was observed in cases of complexation of $\mathrm{Cu}^{2+}$ ions with sudan(I) [31] and sudan(II) [32]. Because of these features of sudan dyes, tartrazine is considered as chromogenic chelating and redox sensitive agent reacting with copper(II) to form $\mathrm{Cu}^{+}-\mathrm{Tz}$ complex under optimum conditions. On the basis of redox sensitivity in the $\mathrm{Cu}(\mathrm{II})$-tartrazine 


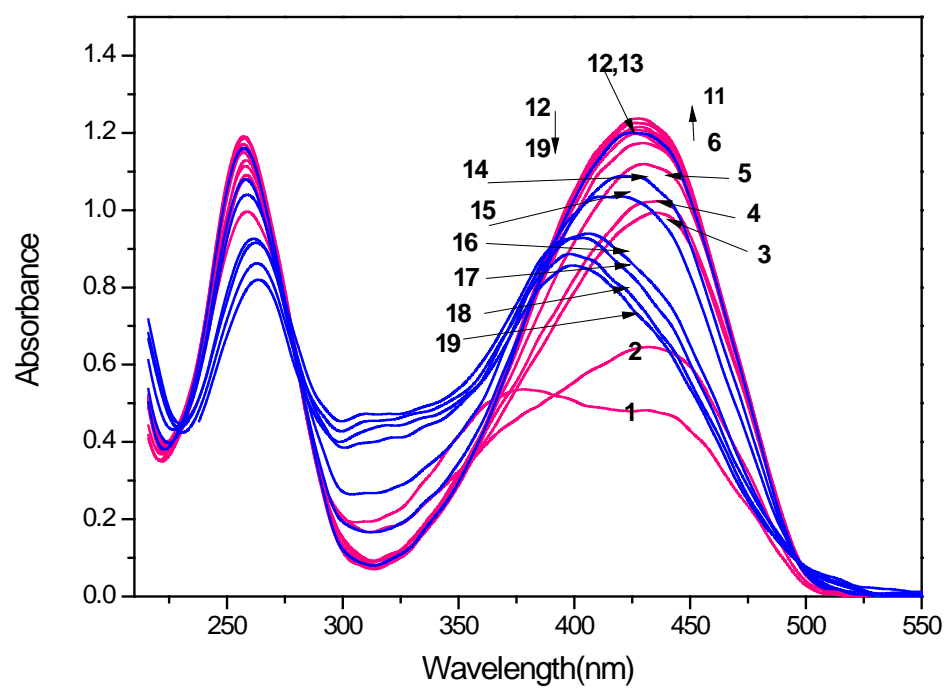

Figure 1. Absorption spectra of $5 \times 10^{-5} \mathrm{~mol} \cdot \mathrm{L}^{-1}$ tartrazine in aqueous medium, $\mathrm{I}=$ $0.1 \mathrm{~mol} \cdot \mathrm{L}^{-1}\left(\mathrm{NaClO}_{4}\right), 25^{\circ} \mathrm{C}$ at different $\mathrm{pH}$ values; $1, \mathrm{pH}=0.86 ; 2, \mathrm{pH}=0.9 ; 3, \mathrm{pH}=$ $1.0 ; 4, \mathrm{pH} 1.17 ; 5, \mathrm{pH}=1.6 ; 6, \mathrm{pH}=2.26 ; 7, \mathrm{pH}=2.73 ; 8, \mathrm{pH}=3.29 ; 9, \mathrm{pH}=3.73$; $10, \mathrm{pH}=4.21 ; 11, \mathrm{pH}=5.7 ; 12, \mathrm{pH}=6.48 ; 13, \mathrm{pH}=7.19 ; 14, \mathrm{pH}=8.7 ; 15, \mathrm{pH}=9.2$; $16, \mathrm{pH}=9.97 ; 17, \mathrm{pH}=10.58 ; 18, \mathrm{pH}=11.12 ; 19, \mathrm{pH}=12.83$.<smiles></smiles>

protonated form of acidic tartrazine $\left(\mathrm{H}_{5} \mathrm{~L}^{+}\right)$ $\lambda=440 \mathrm{~nm}(\mathrm{pH}<3)$<smiles></smiles>

deprotonated form of the salt
$\lambda=420 \mathrm{~nm}$

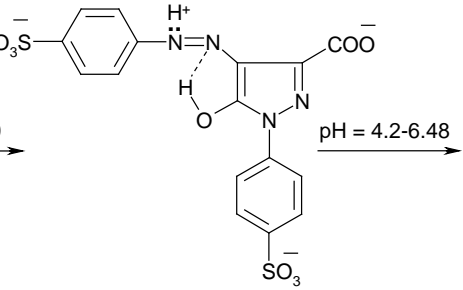
protonated form

$\lambda=430 \mathrm{~nm}$<smiles>O=C([O-])c1nn(-c2ccc(S(=O)(=O)[O-])cc2)c([O-])c1N=Nc1ccc(S(=O)(=O)[O-])cc1</smiles><smiles></smiles>

hydrazone form $\lambda=400 \mathrm{~nm}$ 
interaction in aqueous medium at $\mathrm{I}=0.1 \mathrm{~mol} \cdot \mathrm{L}^{-1}\left(\mathrm{NaClO}_{4}\right), \mathrm{pH}=5.9,30^{\circ} \mathrm{C}$, solution spectrum shows an absorption band with a maximum at $332 \mathrm{~nm}$ corresponding to $\mathrm{Cu}(\mathrm{I})$-Tz complex (MLCT) (Figure 2(a)).

Figure 2(b) shows the absorption spectrum obtained for alkaline $\mathrm{KMnO}_{4}$ solution $\left(\lambda_{\max }=530 \mathrm{~nm}\right)$. With addition of tartrazine solution, an absorption spectrum with two absorption bands at 390, 410 (double headed) and $610 \mathrm{~nm}$ was obtained. The latter band is attributed to the formation of manganate ion as a result of the oxidation of tartrazine with $\mathrm{KMnO}_{4}$ in alkaline medium [33] [34] and the highly intense double headed band is related to Tz oxidized form.

\subsection{Complexation Equilibria of Cu(II) with Tartrazine at Different Temperatures}

The complexation equilibria of $\mathrm{Cu}^{2+}$ with Tz were investigated at $\mathrm{I}=0.1 \mathrm{~mol} \cdot \mathrm{L}^{-1}\left(\mathrm{NaClO}_{4}\right)$ in aqueous medium over the $\mathrm{pH}$ range $3.5-10$ at 293, 303, 313 and $323 \mathrm{~K}$. The solution spectra were recorded in presence of an excess of the metal ion and in equimolar solutions. The absorption spectra for both metal/Tz ratios at various $\mathrm{pH}$ are analogous at the same temperature and exhibit an absorption band at $332 \mathrm{~nm}$.

The absorbance versus $\mathrm{pH}$ graphs for the above solutions at different temperatures show the range of complex
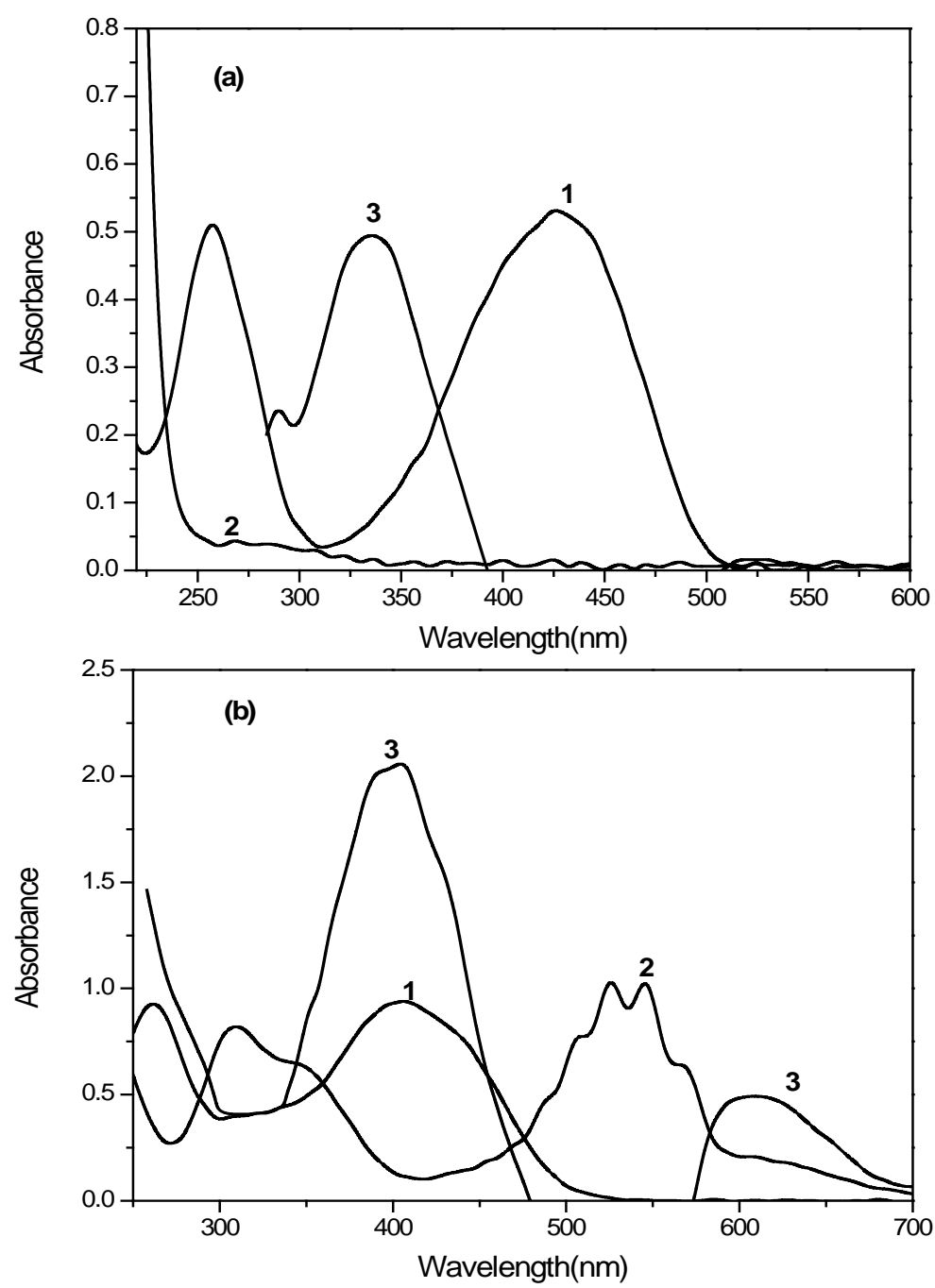

Figure 2. (a) Absorption spectra of Tz-Cu(II) ( $\mathrm{pH}=5.9), \mathrm{I}=0.1 \mathrm{~mol} \cdot \mathrm{L}^{-1}$ (1) $\mathrm{Tz} 2 \times$ $10^{-5} \mathrm{~mol} \cdot \mathrm{L}^{-1}$; (2) $\mathrm{Cu}(\mathrm{II}) 2 \times 10^{-4} \mathrm{~mol} \cdot \mathrm{L}^{-1}$; (3) $1: 1 \mathrm{Tz}-\mathrm{Cu}(\mathrm{II}) ;\left[\mathrm{Cu}^{2+}\right]=[\mathrm{Tz}]=2 \times 10^{-4}$ $\mathrm{mol} \cdot \mathrm{L}^{-1}$. (b) Absorption spectra of $\mathrm{Tz}^{-} \mathrm{KMnO}_{4}$ reaction (in alkaline medium), (1) $\mathrm{Tz} 5$ $\times 10^{-5} \mathrm{~mol} \cdot \mathrm{L}^{-1}$; (2) alkaline $\mathrm{KMnO}_{4}\left(5 \times 10^{-4} \mathrm{~mol} \cdot \mathrm{L}^{-1}\right)$; (3) $\mathrm{Tz}-\mathrm{KMnO}_{4}$ reaction product $[\mathrm{Tz}]=7 \times 10^{-5} \mathrm{~mol} \cdot \mathrm{L}^{-1},\left[\mathrm{KMnO}_{4}\right]=2 \times 10^{-3} \mathrm{~mol} \cdot \mathrm{L}^{-1},[\mathrm{NaOH}]=0.4 \mathrm{~mol} \cdot \mathrm{L}^{-1}$. 
formation (3.0 - 6.5) and existence of one complex equilibria within the $\mathrm{pH}$ range studied (Figure 3(a)). All graphs exhibit a similar descending branch above $\mathrm{pH} 6.5$ which is due to the hydrolysis of the complexed Tz. The absorbance versus $\mathrm{pH}$ graphs for copper-Tz system at different temperatures were interpreted using relations derived earlier by Sommer et al. [35], Idriss et al. [36] [37] and Saleh et al. [34]. The following Equations $(3,4)$ were valid for equimolar and solutions with an excess of metal ion respectively:

$$
\begin{aligned}
& \log \left[\Delta A /\left(\varepsilon_{1} C_{L}-\Delta A\right)^{2}\right]=q \mathrm{pH}+\log \varepsilon_{1}+\log K^{*} \\
& \log \left[\Delta A /\left(\varepsilon_{1} C_{L}-\Delta A\right)\right]=q \mathrm{pH}+\log C_{\mathrm{M}}+\log K^{*}
\end{aligned}
$$

All symbols have their usual meanings. The logarithmic transformation are linear with a slope of $q=2$, indicating the release of two protons during complexation and an intercept including $K^{*}$. By considering the values of the dissociation constants of Tz under our experimental conditions, one can assume the following complexation equilibria with $\mathrm{Cu}(\mathrm{II})$ in the $\mathrm{pH}$ range 3.0 - 6.5 .

$$
\mathrm{Cu}(\mathrm{II})+\mathrm{H}_{2} \mathrm{~L}^{-2} \underset{\mathrm{pH}=3.0-6.5}{\longrightarrow}\left[\mathrm{Cu}^{+}+\mathrm{H}_{2} \mathrm{~L}^{-}\right] \underset{\text { Intermediate state }}{\longrightarrow}\left[\mathrm{Cu}^{+} \mathrm{L}^{3-}\right]+2 \mathrm{H}^{+}, K^{*}
$$

The mean equilibrium constant $K^{*}$ was determined at different temperatures by considering equilibrium A. the stability constant of $\mathrm{Cu}(\mathrm{I})$ complex is related to the equilibrium constant $K^{*}$ by the expression $K_{1}=K^{*} / K_{a 1} \cdot K_{a 2}$. The calculated values of $\log K_{1}$ for the complex at 293, 303, 313 and $323 \mathrm{~K}$ are given in Table 1 . The proposed binding model of Tz-copper complex is shown below.

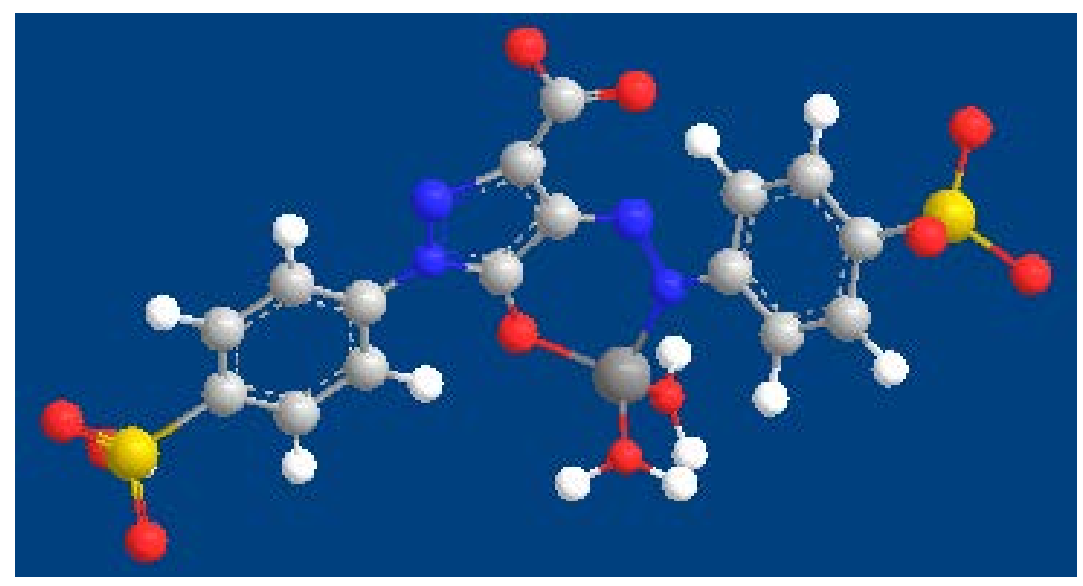

The proposed binding model of Tz with copper(I).

\subsection{Thermodynamic Functions of Tartrazine-Copper(II) Reaction}

According to Van't Hoff equation the values of overall thermodynamic parameters $\Delta \mathrm{G}, \Delta \mathrm{H}$ and $\Delta \mathrm{S}$ accompanying complex formation have been determined (Figure 3(b)). The $\Delta \mathrm{H}$ and $\Delta \mathrm{S}$ values can then be considered as a sum of three contributions, $\mathrm{Cu}(\mathrm{II})-\mathrm{Tz}$ redox reaction, release of $\mathrm{H}_{2} \mathrm{O}$ molecules from octahedral copper(II) ions and metal-ligand bond formation. From Table 1, the -ve value of $\Delta \mathrm{G}$ for the complexation process $\mathrm{Cu}(\mathrm{I})$ - $\mathrm{Tz}$ suggests a spontaneous nature of such process [38]. The +ve value of $\Delta H$ means that this reaction is endothermic favourable at high temperature. The +ve value of $\Delta S$ for the complexation process confirm that the $\mathrm{Cu}(\mathrm{I})-\mathrm{Tz}$ complex formation is entropically favourable [39].

\begin{tabular}{|c|c|c|c|c|c|c|c|}
\hline \multirow{2}{*}{ Complex species } & \multicolumn{4}{|c|}{$\log K_{1}$ at temperature, $K$} & \multirow{2}{*}{$\begin{array}{c}-\Delta \mathrm{G} \\
\mathrm{Kj} \cdot \mathrm{mol}^{-1}\end{array}$} & \multirow{2}{*}{$\begin{array}{c}\Delta \mathrm{H} \\
\mathrm{Kj} \cdot \mathrm{mol}^{-1}\end{array}$} & \multirow{2}{*}{$\underset{\mathrm{J} \cdot \mathrm{mol}^{-1} \cdot \mathrm{K}^{-1}}{\Delta \mathrm{S}}$} \\
\hline & 293 & 303 & 313 & 323 & & & \\
\hline$\left[\mathrm{Cu}^{+} \mathrm{L}^{3-}\right]^{2-}$ & 6.922 & 7.02 & 7.172 & 7.322 & 41.319 & 27.354 & 142.65 \\
\hline
\end{tabular}

Table 1. Stability constants at different temperatures and thermodynamic parameters $\Delta \mathrm{G}, \Delta \mathrm{H}$ and $\Delta \mathrm{S}$ of copper(I)-Tz complex. 


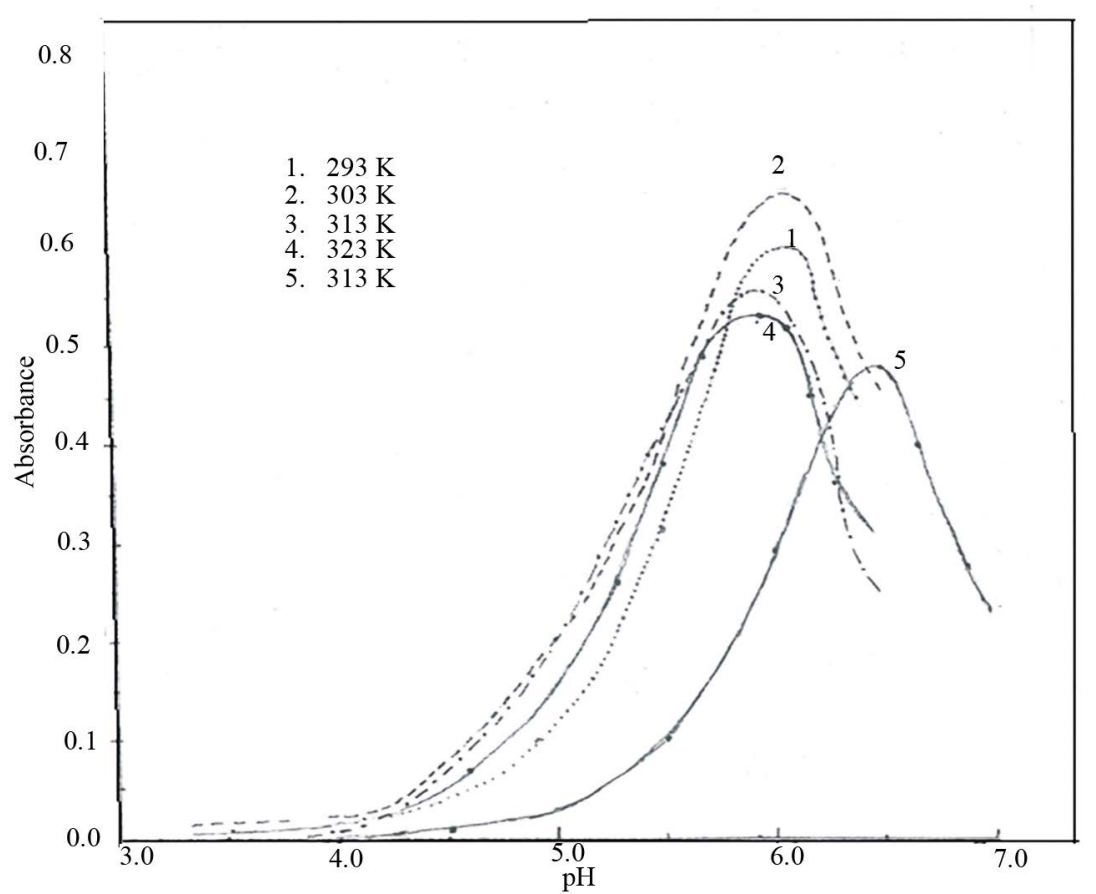

(a)

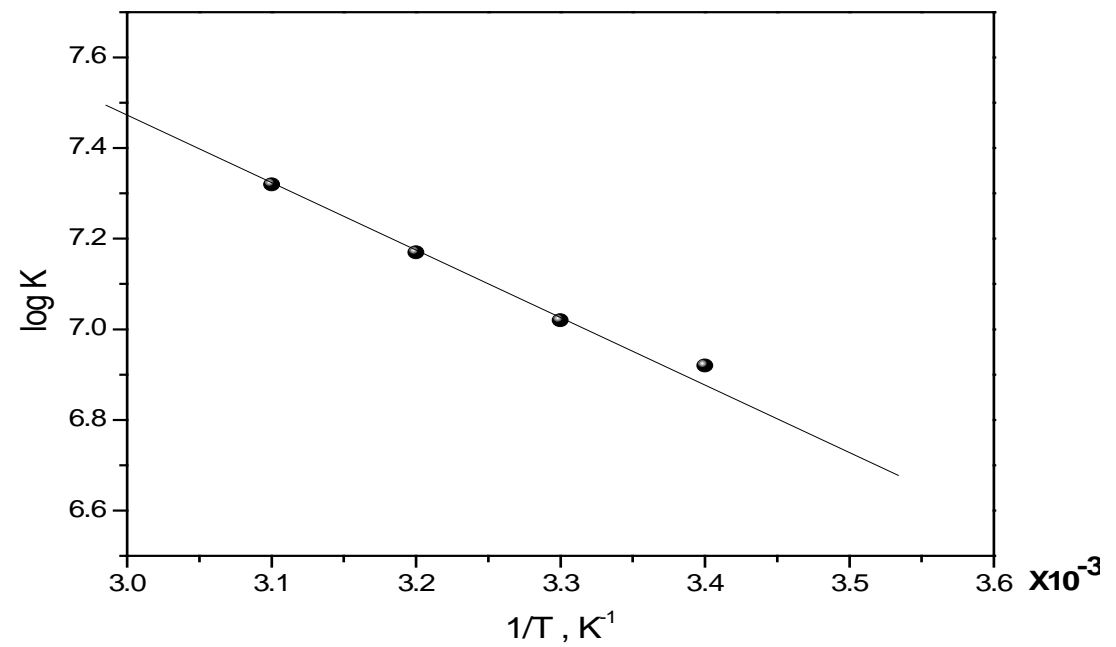

(b)

Figure 3. (a) Absorbance vs $\mathrm{pH}$ graph for $\mathrm{Tz}-\mathrm{Cu}(\mathrm{I})$ complex in aqueous medium, $\mathrm{I}=$ $0.1 \mathrm{~mol} \cdot \mathrm{L}^{-1}\left(\mathrm{NaClO}_{4}\right), \lambda_{\max }=332 \mathrm{~nm}$ at various temperature, $(1-4)[\mathrm{Tz}]=2 \times 10^{-4}$ $\mathrm{mol} \cdot \mathrm{L}^{-1},\left[\mathrm{Cu}^{2+}\right]=6 \times 10^{-4} \mathrm{~mol} \cdot \mathrm{L}^{-1}$ at $293,303,313$, and $323 \mathrm{~K}$ respectively; (5) $[\mathrm{Tz}]=$ $\left[\mathrm{Cu}^{2+}\right]=2 \times 10^{-4} \mathrm{~mol} \cdot \mathrm{L}^{-1}$ at $313 \mathrm{~K}$. (b) Van't Hoff plot of log $K_{1}$ of Tz-Cu(I) complex against $1 / \mathrm{T}$.

\subsection{Optimization of Variables}

\subsubsection{Complexation Method}

In order to optimize the condition we have investigated a number of parameters such as $\mathrm{pH}$, reagent concentration, the temperature and time.

\section{Effect of pH}

With other conditions fixed the effect of $\mathrm{pH}$ on absorbance of $\mathrm{Cu}(\mathrm{I})-\mathrm{Tz}$ complex at $\lambda_{\max }=332 \mathrm{~nm}$ was investigated from $\mathrm{pH} 3.5$ - 10.0. From Figure 3(a), the quantitative determination of $\mathrm{Tz}$ was achieved at $\mathrm{pH}=5.9$. 
In order to determine the best buffer solution at $\mathrm{pH}=5.9$, several buffer systems at isomolar concentration of $0.2 \mathrm{~mol} \cdot \mathrm{L}^{-1}$ were studied. The best analytical sensitivity was obtained in presence of acetate-acetic acid buffer. Next, the effect of buffer volume on analytical sensitivity was also studied in the range of $0.2-2.5 \mathrm{ml}$, and the maximum absorbance was obtained at a buffer volume of $0.5 \mathrm{ml}$. the results are shown in Figure 4(a).

\section{Effect of Copper Concentration}

The effect of copper(II) concentration on the absorbance of the complex was investigated by varying the reagent concentration under the optimum conditions $\left([\mathrm{Tz}]=2 \times 10^{-4} \mathrm{~mol} \cdot \mathrm{L}^{-1}\right), \mathrm{pH}=5.9, \mathrm{~T}=293 \mathrm{~K}$. It is clear from Figure 4(a) that the maximum absorbance was attained with $3.0 \mathrm{ml}$; above this volume, the absorbance remained unchanged. To ensure the complete complexation for determination of tartrazine, $4.0 \mathrm{ml} \mathrm{Cu(II)}$ was used.

\section{Effect of Temperature and Time}

The effect of temperature on the absorbance of the formed complex was studied in aqueous medium at $\mathrm{pH}=$ 5.9 in the range $393-323 \mathrm{~K}$, keeping constant concentration of $\mathrm{Tz}\left(2.0 \times 10^{-4} \mathrm{~mol} \cdot \mathrm{L}^{-1}\right)$ and copper $\left(8.0 \times 10^{-4}\right.$ $\mathrm{mol} \cdot \mathrm{L}^{-1}$ ). The maximum absorbance was obtained at $303 \mathrm{~K}$ (Figure $4(\mathrm{~b})$ ). Under optimum conditions, the reaction time was determined by following the absorbance of the complex at different time intervals. Complete complex formation was attained after 5 min. at $303 \mathrm{~K}$.
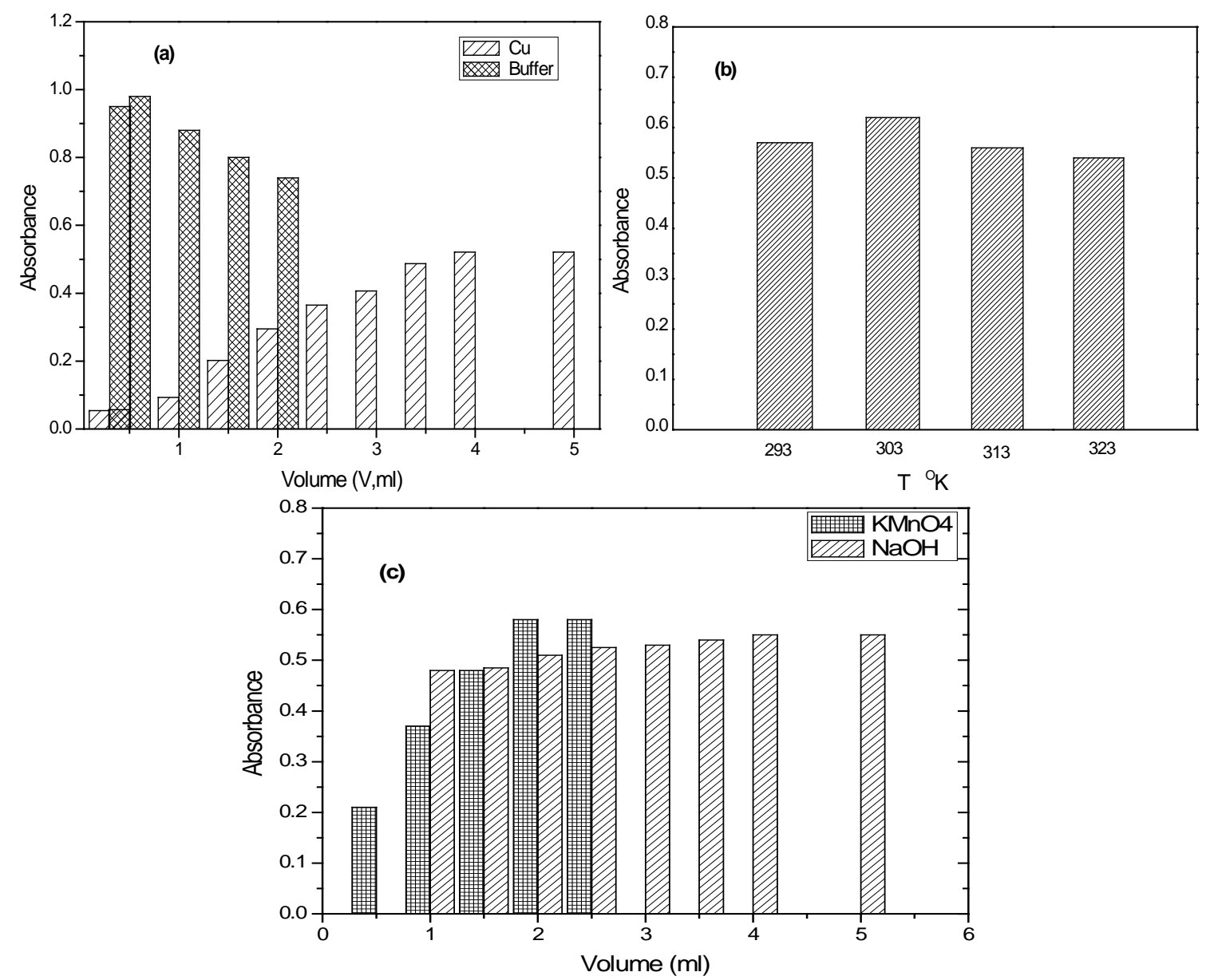

Figure 4. (a) Reaction conditions for complexation reaction at $293 \mathrm{~K},[\mathrm{Tz}]=2 \times 10^{-4} \mathrm{~mol} \cdot \mathrm{L}^{-1}, \lambda_{\max }=332 \mathrm{~nm}, \mathrm{pH}$ = 5.9. (1) Effect of different volumes of $2 \times 10^{-3} \mathrm{~mol} \cdot \mathrm{L}^{-1} \mathrm{Cu}^{2+}$ on absorbance of $\mathrm{Cu}^{+}-\mathrm{Tz}^{3-}$ complex, acetate buffer volume $=1 \mathrm{ml}$. (2) Effect of different acetate buffer volume on absorbance of $\mathrm{Cu}-\mathrm{Tz}$ complex, $\left[\mathrm{Cu}^{2+}\right]=8 \times 10^{-4}$ $\mathrm{mol} \cdot \mathrm{L}^{-1}$. (b) Effect of absolute temperature on absorbance of Tz complex, $[\mathrm{Tz}]=2 \times 10^{-4} \mathrm{~mol} \cdot \mathrm{L}^{-1},\left[\mathrm{Cu}^{2+}\right]=8 \times$ $10^{-4} \mathrm{~mol} \cdot \mathrm{L}^{-1}$; buffer volume $=0.5 \mathrm{ml}$. (c) Reaction conditions for oxidation reaction of $\mathrm{Tz}$ with alkaline $\mathrm{KMnO}_{4}$ at $293 \mathrm{~K},\left[\mathrm{Tz}=1 \times 10^{-4} \mathrm{~mol} \cdot \mathrm{L}^{-1}\right]$. 1) Effect of $\mathrm{KMnO}_{4}\left(1 \times 10^{-2} \mathrm{~mol} \cdot \mathrm{L}^{-1}\right)\left(\right.$ by volume), $[\mathrm{NaOH}]=0.4 \mathrm{~mol} \cdot \mathrm{L}^{-1}, \mathrm{t}$ $=60 \mathrm{~min}$. 2) Effect of $\mathrm{NaOH}\left(1.0 \mathrm{~mol} \cdot \mathrm{L}^{-1}\right)$ (by volume), $\left[\mathrm{KMnO}_{4}\right]=2 \times 10^{-3} \mathrm{~mol} \cdot \mathrm{L}^{-1}, \mathrm{t}=60 \mathrm{~min}$. 


\subsection{2. $\mathrm{KMnO}_{4}$ Oxidation Method}

Redox reactions have been used as the basis for the development of simple and sensitive spectrophotometric methods for the determination of many compounds [33] [40]. Tartrazine reacts with $\mathrm{KMnO}_{4}$ in strongly alkaline medium producing green manganate $\left(\lambda_{\max }=610 \mathrm{~nm}\right.$ ) (Figure 2(b)). During the current study the produced colour intensity increased gradually with time to reach maximum after $60 \mathrm{~min}$ and was stable for at least $24 \mathrm{~h}$. The factors affecting the formation of manganate ions were further studied and optimized.

\section{Effect of $\mathrm{NaOH}$ and $\mathrm{KMnO}_{4}$}

The dependence of redox reaction on the volume of $\mathrm{NaOH}\left(1.0 \mathrm{~mol} \cdot \mathrm{L}^{-1}\right)$ was investigated in the range 1.0 $5.0 \mathrm{ml}$. The results show that maximum absorbance was obtained using $4.0 \mathrm{ml}$ of $1.0 \mathrm{~mol} \cdot \mathrm{L}^{-1} \mathrm{NaOH}$ with no significant changes indicated as the volume was increased (Figure 4(c)). Under optimum conditions, the dependence of redox reaction on the volume of $\mathrm{KMnO}_{4}$ was investigated over the range from $0.5-3.0 \mathrm{ml}\left(1 \times 10^{-2}\right.$ $\left.\mathrm{mol} \cdot \mathrm{L}^{-1}\right)$. The results show that the maximum absorbance was obtained using $2.0 \mathrm{ml}$ of $1 \times 10^{-2} \mathrm{~mol} \cdot \mathrm{L}^{-1}$ $\mathrm{KMnO}_{4}$ (Figure 4(c)).

\subsubsection{Stoichiometry of Tartrazine Reactions}

The stoichiometryt of tartrazine reaction with $\mathrm{Cu}(\mathrm{II})$ or $\mathrm{KMnO}_{4}$ was established by the continuous variation method [34] [41]. The solutions having $\mathrm{C}_{\mathrm{o}}=\mathrm{C}_{\mathrm{R}}+\mathrm{C}_{\mathrm{Tz}}=6.0 \times 10^{-4} \mathrm{~mol} \cdot \mathrm{L}^{-1}$ at $\mathrm{pH} 5.9$ or $>11.0$. The plot of absorbance versus mole fraction of reagent at $\lambda_{\max } 332$ or $610 \mathrm{~nm}$, reveals the formation of 1:1 (Tz:copper) complex and 1:2 (Tz:KMnO 4$)$.

\subsection{Quantification}

\subsubsection{Validation of the Proposed Methods}

For our two methods (I, II) the ranges of linearity of absorbance as a function of food additive Tz concentration provide a satisfactory measure of the sensitivity of the method. Under the optimum conditions the absorbance of the complex (Figure 5) or manganate obeys Beer's law in Tz concentration range of 10.69 - 85.50 or 5.34 $34.12 \mu \mathrm{g} \cdot \mathrm{ml}^{-1}$ respectively. For the two proposed methods (I, II), the molar absorptivity and Sandell sensitivity [42] values are $0.361 \times 10^{4}, 0.80 \times 10^{4} \mathrm{~L} \cdot \mathrm{mol}^{-1} \cdot \mathrm{cm}^{-1}$ and $0.1480,0.0668 \mu \mathrm{g} \cdot \mathrm{cm}^{-2}$ respectively. The regression equations, correlation coefficient, limit of detection, and limit of quantification [43] were also calculated and summarized in Table 2.

\subsubsection{Accuracy and Precision}

The accuracy and precision of the proposed spectrophotometric methods were determined at three different concentration levels of additive food colour-Tz by analyzing five replicate samples of each concentration. The relative standard deviation (R.S.D\%) obtained for the analytical results did not exceed 2\% (Table 3) which proved a high reproducibility of the results and precision of the methods.

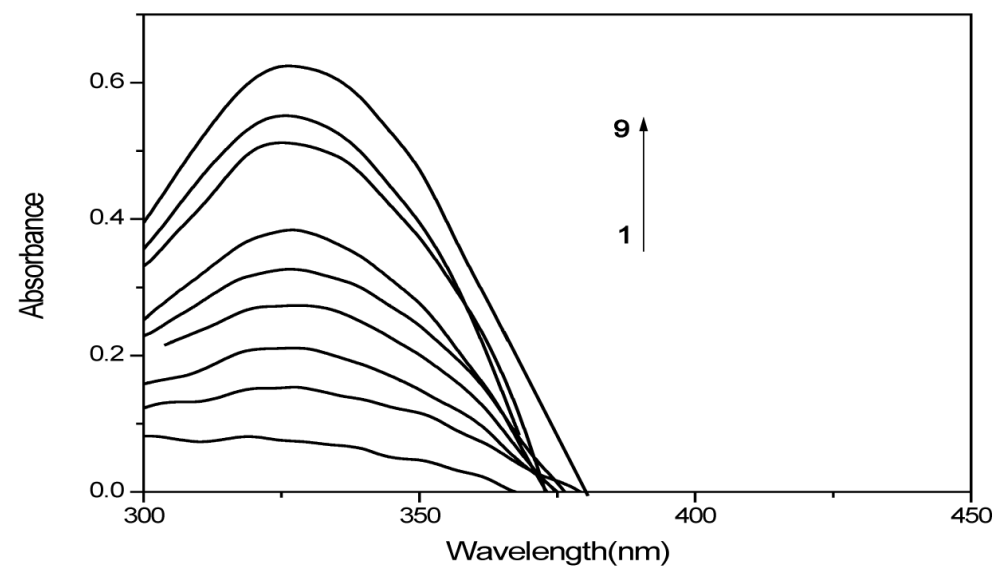

Figure 5. Absorption spectra of tartrazine-copper complex, $\mathrm{pH}=5.9$ (acetate buffer), tartrazine concentration range $2 \times 10^{-5}(1)$ to $2.0 \times 10^{-4} \mathrm{~mol} \cdot \mathrm{L}^{-1}(9)$ with regular successive additions in presence of $8.0 \times 10^{-4} \mathrm{~mol} \cdot \mathrm{L}^{-1} \mathrm{Cu}(\mathrm{II})$ at $303 \mathrm{~K}$. 
Table 2. Summary of optical and regression characteristic of the proposed methods for determination of tartrazine.

\begin{tabular}{ccc}
\hline \multicolumn{1}{c}{ Method/reagent } & Copper(II) & $\mathrm{KMnO}_{4}$ \\
Parameter & Colourless & Green \\
$\lambda_{\max }(\mathrm{nm})$ & 332 & 610 \\
Beer's law limits $\left(\mu \mathrm{g} \cdot \mathrm{ml}^{-1}\right)$ & $10.69-85.50$ & $5.34-34.12$ \\
Ringborn limts $\left(\mu \mathrm{g} \cdot \mathrm{ml}^{-1}\right)$ & $12.59-81.28$ & $7.08-31.62$ \\
Molar absorptivity $\left(\mathrm{L} \cdot \mathrm{mol}^{-1} \cdot \mathrm{cm}^{-1}\right)$ & $0.361 \times 10^{4}$ & $0.80 \times 10^{4}$ \\
Sandel's sensitivity $\left(\mu \mathrm{g} \cdot \mathrm{cm}^{-2}\right)$ & 0.1480 & 0.0668 \\
Regression equation A $=\mathrm{a}+\mathrm{bc}$ & $\mathrm{A}=6.55 \times 10^{-3} \mathrm{C}-8.62 \times 10^{-4}$ & $\mathrm{~A}=0.0147 \mathrm{C}+6.79 \times 10^{-3}$ \\
Slope (b) & $6.55 \times 10^{-3}$ & 0.0147 \\
Intercept (a) & $8.62 \times 10^{-4}$ & $6.79 \times 10^{-3}$ \\
Correlation coefficient & 0.9999 & 0.9969 \\
Limit of detection (LOD) $\left(\mu \mathrm{g} \cdot \mathrm{ml}^{-1}\right)$ & 0.101 & 0.355 \\
Limit of quantification (LOQ) $\left(\mu \mathrm{g} \cdot \mathrm{ml}{ }^{-1}\right)$ & 0.305 & 1.075 \\
\hline
\end{tabular}

Table 3. Summary of accuracy and precision of the proposed methods for determination of tartrazine in pure form.

\begin{tabular}{|c|c|c|c|c|c|}
\hline \multirow{2}{*}{ Method/Reagent } & \multicolumn{2}{|c|}{ Amount $\mu \mathrm{g} \cdot \mathrm{ml}^{-1}$} & \multirow{2}{*}{ RSD \% } & \multirow{2}{*}{ Recovery \% } & \multirow{2}{*}{ C.L ${ }^{b}$} \\
\hline & Taken & Found $\pm \mathrm{SD}^{\mathrm{a}}$ & & & \\
\hline \multirow{3}{*}{$\begin{array}{c}\mathrm{Cu}(\mathrm{II}) \\
\text { Intraday assay }\end{array}$} & 32.062 & $31.929 \pm 0.11$ & 0.34 & 99.585 & \pm 0.137 \\
\hline & 53.437 & $51.777 \pm 0.13$ & 0.25 & 96.894 & \pm 0.162 \\
\hline & 64.124 & $63.532 \pm 0.20$ & 0.31 & 99.076 & \pm 0.249 \\
\hline \multirow{3}{*}{ Intreday assay } & 32.062 & $31.166 \pm 0.12$ & 0.39 & 97.205 & \pm 0.149 \\
\hline & 53.437 & $52.54 \pm 0.15$ & 0.29 & 98.321 & \pm 0.186 \\
\hline & 64.124 & $63.838 \pm 0.19$ & 0.30 & 99.554 & \pm 0.236 \\
\hline \multirow{3}{*}{$\begin{array}{l}\mathrm{KMnO}_{4} \\
\text { Intraday }\end{array}$} & 16.031 & $16.001 \pm 0.05$ & 0.31 & 99.813 & \pm 0.062 \\
\hline & 26.719 & $26.205 \pm 0.07$ & 0.27 & 98.076 & \pm 0.087 \\
\hline & 32.062 & $32.395 \pm 0.11$ & 0.34 & 101.039 & \pm 0.137 \\
\hline
\end{tabular}

a) Mean for 5 independed analysis. b) C.L., confidence limit at 95\% confidence level at 4 degree of freedom $(t=2.776)$.

\subsubsection{Intraday and Interday Precision and Accuracy}

Under optimum conditions the intraday precision was carried out for our procedures through replicate analysis $\left(\mathrm{n}=5\right.$ ) for Tz corresponding to 32.062, 53.437, $64.124 \mu \mathrm{g} \cdot \mathrm{ml}^{-1}$ (method I) and 16.031, 26.719, $32.062 \mu \mathrm{g} \cdot \mathrm{ml} \mathrm{l}^{-1}$ (method II). The interday precision was also evaluated through replicate analysis of the standard Tz for three consecutive days at the same concentration levels as in within day precision. The results of these assays are reported in Table 3. For intraday and interday precision, the recovery and RSD values were in the range of 96.89\% - $101.04 \%$ and $0.25 \%$ to $0.39 \%$ respectively. The green manganate ions produced from $\mathrm{Tz}-\mathrm{KMnO}_{4}$ reaction in alkaline medium was stable only for 24 hours.

\subsubsection{Analytical Recovery and Matrix Effects}

To investigate the selectivity of the proposed methods, the effect of various substances on the determination of $\mathrm{Tz}$ (53.437 and $26.719 \mathrm{mg} \cdot \mathrm{L}^{-1}$ ) for method I and II respectively was tested under optimum conditions. Several representative potential interferences such as inorganic cations, anions, molecular species and dyes were investigated individually for their effect on Tz recovery. Tolerance limits were defined by the concentration of interferents which caused on $<5 \%$ error in the determination of Tz. The obtained mean recoveries and standard deviation ranged between $99.0 \%-96.0 \%$ and $\pm 1.0-2.0$ respectively are shown in Table 4 . These results proved the accuracy of the proposed methods and absence of interference from common matrix. The accuracy of our method was also checked by studying the influence of various dyes on the recovery of Tz. Tartrazine determination 
Table 4. Matrix effects on the recovery of tartrazine $(E=102)$.

\begin{tabular}{ccccc}
\hline \multirow{2}{*}{ Matrix components } & \multicolumn{2}{c}{ Complexation method } & \multicolumn{2}{c}{ Oxidation method } \\
\cline { 2 - 5 } & $\begin{array}{c}\text { Concentration } \\
\mathrm{mg} \cdot \mathrm{L}^{-1}\end{array}$ & Recovery \% & Concentration $\mathrm{mg} \cdot \mathrm{L}^{-1}$ & Recovery $\%$ \\
\hline $\begin{array}{c}\text { 1) } \mathrm{Na}^{+}, \mathrm{K}^{+}, \mathrm{Mg}^{2+}, \mathrm{Ca}^{2+}, \mathrm{Cl}^{-}, \mathrm{SO}_{4}^{2-}, \quad \mathrm{PO}_{4}^{3-} \\
\text { 2) Citrate, stearat, fumarate, aspartame, gelatin, sugar, } \\
\text { L-ascopric acid. }\end{array}$ & 3000 & $99.0 \pm 1.0$ & 2500 & $98.0 \pm 1.5$ \\
3) Sunset yellow & 1000 & $98.0 \pm 1.0$ & 8.0 & $98.5 \pm 1.0$ \\
4) Tropaeolin ooo & 4.5 & $97.5 \pm 1.5$ & 3.5 & $97.0 \pm 1.5$ \\
5) Allura red Ac & 6.1 & $96.5 \pm 2.0$ & 4.5 & $96.0 \pm 2.0$ \\
& 5.0 & $97.0 \pm 2.0$ & 4.0 & $96.8 \pm 1.0$ \\
\hline
\end{tabular}

Table 5. Statistical analysis of results obtained by the complexation method for tartrazine in powdered drink samples.

\begin{tabular}{|c|c|c|c|c|c|c|c|c|c|c|c|}
\hline \multirow{2}{*}{$\begin{array}{l}\text { Drink }^{a} \\
\text { sample }\end{array}$} & \multirow{2}{*}{$\begin{array}{l}\text { Present } \\
\mu \mathrm{g} \cdot \mathrm{ml}^{-1}\end{array}$} & \multirow{2}{*}{$\begin{array}{c}\text { Added } \\
\mu \mathrm{g} \cdot \mathrm{ml}^{-1}\end{array}$} & \multirow{2}{*}{$\begin{array}{c}\text { Found } \\
\mu \mathrm{g} \cdot \mathrm{ml}^{-1}\end{array}$} & \multirow{2}{*}{ \pm RSD $\%$} & \multirow{2}{*}{ Recovery \% } & \multicolumn{2}{|c|}{ Mean } & \multirow{2}{*}{ t-value ${ }^{b}$} & \multirow{2}{*}{ F-value $^{\mathrm{b}}$} & \multicolumn{2}{|c|}{ Reported method ${ }^{(41)}$} \\
\hline & & & & & & Recovery \% & $\pm \mathrm{RSD} \%$ & & & Recovery \% & $\pm \mathrm{RSD} \%$ \\
\hline Apple & 3.741 & $\begin{array}{l}10.690 \\
21.375 \\
32.070\end{array}$ & $\begin{array}{l}13.893 \\
24.578 \\
35.800\end{array}$ & $\begin{array}{l}0.68 \\
0.69 \\
0.73\end{array}$ & $\begin{array}{c}96.48 \\
97.86 \\
100.02\end{array}$ & 98.121 & 0.70 & 1.98 & 1.15 & 97.5 & 0.75 \\
\hline Orange & 1.603 & $\begin{array}{l}10.690 \\
21.375 \\
32.070\end{array}$ & $\begin{array}{l}11.756 \\
23.510 \\
33.130\end{array}$ & $\begin{array}{l}0.55 \\
0.62 \\
0.63\end{array}$ & $\begin{array}{c}95.632 \\
102.320 \\
98.390\end{array}$ & 98.75 & 0.60 & - & - & - & - \\
\hline Tamarind & 2.1375 & $\begin{array}{l}10.690 \\
21.375 \\
42.760\end{array}$ & $\begin{array}{l}12.825 \\
22.440 \\
34.199\end{array}$ & $\begin{array}{l}0.60 \\
0.63 \\
0.72\end{array}$ & $\begin{array}{l}99.97 \\
95.44 \\
99.96\end{array}$ & 98.46 & 0.65 & - & - & - & - \\
\hline
\end{tabular}

a) From local markets of Assiut city, Egypt. b) Theoretical t-value $(v=4)$ and F-value $(v=4.4)$ at 95\% confidence level are 2.78 and 6.39 .

Table 6. Statistical analysis of results obtained by the complexation method for tartrazine in powdered gelatin.

\begin{tabular}{|c|c|c|c|c|c|c|c|c|c|c|c|}
\hline \multirow{2}{*}{$\begin{array}{l}\text { Gelatin }^{\mathrm{a}} \\
\text { sample }\end{array}$} & \multirow{2}{*}{$\begin{array}{l}\text { Present } \\
\mu \mathrm{g} \cdot \mathrm{ml}^{-1}\end{array}$} & \multirow{2}{*}{$\begin{array}{c}\text { Added } \\
\mu \mathrm{g} \cdot \mathrm{ml}^{-1}\end{array}$} & \multirow{2}{*}{$\begin{array}{c}\text { Found } \\
\mu \mathrm{g} \cdot \mathrm{ml}^{-1}\end{array}$} & \multirow{2}{*}{$\pm \mathrm{RSD} \%$} & \multirow{2}{*}{ Recovery \% } & \multicolumn{2}{|c|}{ Mean } & \multirow{2}{*}{ t-value ${ }^{b}$} & \multirow{2}{*}{ F-value ${ }^{b}$} & \multicolumn{2}{|c|}{ Reported method $^{(21)}$} \\
\hline & & & & & & Recovery \% & \pm RSD $\%$ & & & Recovery \% & \pm RSD $\%$ \\
\hline Lemon & 2.137 & $\begin{array}{l}10.690 \\
21.375 \\
32.070\end{array}$ & $\begin{array}{l}12.82 \\
22.44 \\
33.13\end{array}$ & $\begin{array}{l}0.54 \\
0.62 \\
0.64\end{array}$ & $\begin{array}{l}99.92 \\
95.44 \\
96.84\end{array}$ & 97.40 & 0.60 & 1.49 & & 97.0 & - \\
\hline Apricot & 3.206 & $\begin{array}{l}10.690 \\
21.375 \\
32.070\end{array}$ & $\begin{array}{l}12.820 \\
23.512 \\
35.270\end{array}$ & $\begin{array}{l}0.66 \\
0.72 \\
0.75\end{array}$ & $\begin{array}{l}92.25 \\
95.57 \\
99.98\end{array}$ & 95.93 & 0.71 & - & - & - & - \\
\hline Banana & 2.1375 & $\begin{array}{l}10.690 \\
21.375 \\
32.070\end{array}$ & $\begin{array}{l}12.820 \\
22.440 \\
34.199\end{array}$ & $\begin{array}{l}0.59 \\
0.70 \\
0.63\end{array}$ & $\begin{array}{l}99.94 \\
95.45 \\
99.96\end{array}$ & 98.45 & 0.64 & - & - & - & - \\
\hline Pineapple & 3.206 & $\begin{array}{l}10.690 \\
21.375 \\
32.070\end{array}$ & $\begin{array}{l}13.894 \\
23.512 \\
34.199\end{array}$ & $\begin{array}{l}0.66 \\
0.69 \\
0.69\end{array}$ & $\begin{array}{l}99.95 \\
95.66 \\
96.94\end{array}$ & 97.52 & 0.68 & - & - & - & - \\
\hline Green apple & 1.068 & $\begin{array}{l}10.690 \\
21.375 \\
32.070\end{array}$ & $\begin{array}{l}11.75 \\
21.37 \\
32.06\end{array}$ & $\begin{array}{l}0.67 \\
0.69 \\
0.74\end{array}$ & $\begin{array}{l}99.93 \\
95.23 \\
96.67\end{array}$ & 97.29 & 0.70 & - & - & - & - \\
\hline Peach & 1.068 & $\begin{array}{l}10.690 \\
21.375 \\
32.070\end{array}$ & $\begin{array}{l}10.687 \\
22.440 \\
33.130\end{array}$ & $\begin{array}{l}0.66 \\
0.69 \\
0.72\end{array}$ & $\begin{array}{l}90.89 \\
99.98 \\
99.97\end{array}$ & 96.95 & 0.69 & - & - & - & - \\
\hline
\end{tabular}

a) From local markets of Assiut city, Egypt. b) Theoretical t-value $(v=4)$ and F-value $(v=4.4)$ at $95 \%$ confidence level are 2.78 and 6.39 .

was possible in presence of $0.045 \mathrm{mg} / 10 \mathrm{ml}$ sunset yellow ( $0.035 \mathrm{mg}$ in case of method II), $0.05 \mathrm{mg}$ Allura red ( $0.04 \mathrm{mg}$ in case of method II) and $0.061 \mathrm{mg}$ Tropaeolin 000 ( $0.045 \mathrm{mg}$ in case of method II). This was attributed to the great sensitivity of the methods that necessitated dilution for the food sample and consequently the matrix beyond their interference capability. 


\subsection{Applications}

The complexation method was successfully applied to the determination of Tz in two different commercial food products (powered drink and powdered gelatin samples). To investigate the applicability of the proposed method, recovery experiments were performed using multiple points standard addition method. For this purpose, a known amount of $\mathrm{Tz}$ was spiked to the formulated preparations and the total amount of the dye was estimated. The results are summarized in Table 5 and Table 6. The $\mathrm{t}$ - and F-tests indicated no significant differences between the calculated and theoretical values of both the proposed and the reported methods [24] [44] at 95\% confidence level, which indicate good precision and accuracy in the analysis of investigated $\mathrm{Tz}$ in commercial food products.

\section{Conclusion}

In this paper, two spectrophotometric methods for the determination of $\mathrm{Tz}$ with $\mathrm{Cu}(\mathrm{II})$ and $\mathrm{KMnO}_{4}$ were proposed and successfully validated. The methods were based on the redox reaction with $\mathrm{Cu}(\mathrm{II})$ followed by complex formation and oxidation with strongly alkaline $\mathrm{KMnO}_{4}$. The positive value of change in enthalpy $(\Delta \mathrm{H})$ for complexation reaction suggested that the reaction was endothermic favourable at high temperature. The negative value of free energy change indicated that copper-Tz redox reaction, dissociation of the ligand and complexation process were spontaneous. It was found that the complexation method was selective and sensitive enough to enable the determination of lower amounts of $\mathrm{Tz}$ and could be applied to the food quality control.

\section{References}

[1] Argetino, C.A. (2010) Chapter XII. http://www.anmat.gov.ar/alimentos/codigea/CAPITULO_II.pdf

[2] FDA (2007) Summary of Color Additives for Use in United States in Foods, Drugs, Cosmetics and Medical Devices. FDA.

[3] Tanaka, T. (2006) Reproductive and Neurobehavioural Toxicity Study of Tartrazine Administered to Mice in the Diet. Food and Chemical Toxicology, 44, 179-187. http://dx.doi.org/10.1016/j.fct.2005.06.011

[4] Michel, O., Naeije, N., Bracamonte, M., Duchateau, J. and Sergysels, R. (1984) Decreased Sensitivity to Tartrazine after Aspirin Desensitization in an Asthmatic Patient Intolerant to Both Aspirin and Tartrazine. Annals of Allergy, 52, 368-370.

[5] Moutinho, I.L.D., Bertges, L.C. and Assis, R.V.C. (2007) Prolonged Use of the Food Dye Tartrazine (FD\&C Yellow $\mathrm{n}^{\circ}$ 5) and Its Effects on the Gastric Mucosa of Wistar Rats. Brazilian Journal of Biology, 67, 141-145. http://dx.doi.org/10.1590/S1519-69842007000100019

[6] Al-Degs, Y.S. (2009) Determination of Three Dyes in Commercial Soft Drinks Using HLA/GO and Liquid Chromatography. Food Chemistry, 117, 485-490. http://dx.doi.org/10.1016/j.foodchem.2009.04.097

[7] Alves, S.P., Brum, D.M., de Andrade, É.C.B. and Netto, A.D.P. (2008) Determination of Synthetic Dyes in Selected Foodstuffs by High Performance Liquid Chromatography with UV-DAD Detection. Food Chemistry, 107, 489-496. http://dx.doi.org/10.1016/j.foodchem.2007.07.054

[8] Garcıa-Falcón, M.S. and Simal-Gandara, J. (2005) Determination of Food Dyes in Soft Drinks Containing Natural Pigments by Liquid Chromatography with Minimal Clean-Up. Food Control, 16, 293-297. http://dx.doi.org/10.1016/j.foodcont.2004.03.009

[9] Husain, A., Sawaya, W., Al-Omair, A., Al-Zenki, S., Al-Amiri, H., Ahmed, N. and Al-Sinan, M. (2006) Estimates of Dietary Exposure of Children to Artificial Food Colours in Kuwait. Food Additives and Contaminants, 23, 245-251. http://dx.doi.org/10.1080/02652030500429125

[10] Ma, M., Luo, X., Chen, B., Su, S. and Yao, S. (2006) Simultaneous Determination of Water-Soluble and Fat-Soluble Synthetic Colorants in Foodstuff by High-Performance Liquid Chromatography-Diode Array Detection-Electrospray Mass Spectrometry. Journal of Chromatography A, 1103, 170-176. http://dx.doi.org/10.1016/j.chroma.2005.11.061

[11] Minioti, K.S., Sakellariou, C.F. and Thomaidis, N.S. (2007) Determination of 13 Synthetic Food Colorants in WaterSoluble Foods by Reversed-Phase High-Performance Liquid Chromatography Coupled with Diode-Array Detector. Analytica Chimica Acta, 583, 103-110. http://dx.doi.org/10.1016/j.aca.2006.10.002

[12] Poul, M., Jarry, G., Elhkim, M.O. and Poul, J.M. (2009) Lack of Genotoxic Effect of Food Dyes Amaranth, Sunset Yellow and Tartrazine and Their Metabolites in the Gut Micronucleus Assay in Mice. Food and Chemical Toxicology, 47, 443-448. http://dx.doi.org/10.1016/j.fct.2008.11.034

[13] Ghoreishi, S.M., Behpour, M. and Golestaneh, M. (2012) Simultaneous Determination of Sunset Yellow and Tartra- 
zine in Soft Drinks Using Gold Nanoparticles Carbon Paste Electrode. Food Chemistry, 132, 637-641. http://dx.doi.org/10.1016/j.foodchem.2011.10.103

[14] KAPOR, M.A., Yamanaka, H., Carneiro, P.A. and Zanoni, M.V.B. (2001) Electroanalysis of Food Dyes: Determination of Indigo-Carmine and Tartrazine. Eclética Química, 26, 53-68.

[15] Silva, M.L.S., Garcia, M.B.Q., Lima, J.L. and Barrado, E. (2007) Voltammetric Determination of Food Colorants Using a Polyallylamine Modified Tubular Electrode in a Multicommutated Flow System. Talanta, 72, 282-288. http://dx.doi.org/10.1016/j.talanta.2006.10.032

[16] López-de-Alba, P.L., Michelini-Rodriguez, L.I., Wróbel, K. and Amador-Hernández, J. (1997) Extraction of Sunset Yellow and Tartrazine by Ion-Pair Formation with Adogen-464 and Their Simultaneous Determination by Bivariate Calibration and Derivative Spectrophotometry. Analyst, 122, 1575-1579. http://dx.doi.org/10.1039/a702268i.

[17] Nevado, J.B., Flores, J.R., Cabanillas, C.G., Llerena, M.V. and Salcedo, A.C. (1998) Resolution of Ternary Mixtures of Tartrazine, Sunset Yellow and Ponceau 4R by Derivative Spectrophotometric Ratio Spectrum-Zero Crossing Method in Commercial Foods. Talanta, 46, 933-942. http://dx.doi.org/10.1016/S0039-9140(97)00348-2

[18] Berzas, J.J., Flores, J.R., Llerena, M.V. and Farinas, N.R. (1999) Spectrophotometric Resolution of Ternary Mixtures of Tartrazine, Patent Blue V and Indigo Carmine in Commercial Products. Analytica Chimica Acta, 391, 353-364. http://dx.doi.org/10.1016/S0003-2670(99)00215-9

[19] Vidotti, E.C., Cancino, J.C., Oliveira, C.C. and Rollemberg, M.D.C.E. (2005) Simultaneous Determination of Food Dyes by First Derivative Spectrophotometry with Sorption onto Polyurethane Foam. Analytical Sciences, 21, 149-153. http://dx.doi.org/10.2116/analsci.21.149

[20] Vidotti, E.C. and Rollemberg, M.D.C.E. (2006) Derivative Spectrophotometry: A Simple Strategy for Simultaneous Determination of Food Dyes. Química Nova, 29, 230-233. http://dx.doi.org/10.1590/S0100-40422006000200010

[21] Llamas, N.E., Garrido, M., Di Nezio, M.S. and Band, B.S.F. (2009) Second Order Advantage in the Determination of Amaranth, Sunset Yellow FCF and Tartrazine by UV-Vis and Multivariate Curve Resolution-Alternating Least Squares. Analytica Chimica Acta, 655, 38-42. http://dx.doi.org/10.1016/j.aca.2009.10.001

[22] Ni, Y., Wang, Y. and Kokot, S. (2009) Simultaneous Kinetic Spectrophotometric Analysis of Five Synthetic Food Colorants with the Aid of Chemometrics. Talanta, 78, 432-441. http://dx.doi.org/10.1016/j.talanta.2008.11.035

[23] Schenone, A.V., Culzoni, M.J., Marsili, N.R. and Goicoechea, H.C. (2013) Determination of Tartrazine in Beverage Samples by Stopped-Flow Analysis and Three-Way Multivariate Calibration of Non-Linear Kinetic-Spectrophotometric Data. Food chemistry, 138, 1928-1935. http://dx.doi.org/10.1016/j.foodchem.2012.11.126

[24] Sahraei, R., Farmany, A. and Mortazavi, S.S. (2013) A Nanosilver-Based Spectrophotometry Method for Sensitive Determination of Tartrazine in Food Samples. Food chemistry, 138, 1239-1242. http://dx.doi.org/10.1016/j.foodchem.2012.11.029

[25] Vogel, A.I. (1973) A Text Book of Quantitative Inorganic Analysis. 3rd Edition, Longman, London.

[26] Nair, V.S.K. and Parthasarathy, S. (1971) Studies on Metal Complexes in Aqueous Solution-VII: 4-Nitro and 4-Methyl Phthalates of Some Transition Metals. Journal of Inorganic and Nuclear Chemistry, 33, 3019-3024. http://dx.doi.org/10.1016/0022-1902(71)80067-2

[27] Dickerson, R.E., Geis, I. and Benjamin, I.W.A. (1976) Chemistry, Matter and the Universe. California, USA.

[28] Ives, D.J.G. (1972) Chemical Thermodynamics, University Chemistry, Macdonald Technical and Scientific.

[29] Kuban, V. and Havel, J. (1973) Some 2-(2-Thiazolylazo)-4-Methoxyphenol (TAMP) Complex Equilibria, Acid-Base Properties of TAMP in Water and in Various Mixed Solvents. Acta Chemica Scandinavica, 27, 528-540. http://dx.doi.org/10.3891/acta.chem.scand.27-0528

[30] Wu, L.P., Li, Y.F., Huang, C.Z. and Zhang, Q. (2006) Visual Detection of Sudan Dyes Based on the Plasmon Resonance Light Scattering Signals of Silver Nanoparticles. Analytical Chemistry, 7, 5570-5577. http://dx.doi.org/10.1021/ac0603577

[31] Huo, J., Guo, Y., Meng, S., Wang, M. and Wang, Y. (2010) Complex Formation of Sudan I with Cu (II) and Its Identification from Chilli Species. 4th International Conference on Bioinformatics and Biomedical Engineering (iCBBE), Chengdu, 18-20 June 2010, 1-4.

[32] Gürkan, R. and Altunay, N. (2013) A Reliable Method of Quantification of Trace Copper in Beverages with and without Alcohol by Spectrophotometry after Cloud Point Extraction. Química Nova, 36, 1146-1154. http://dx.doi.org/10.1590/S0100-40422013000800012

[33] Hassan, E.M. and Belal, F. (2002) Kinetic Spectrophotometric Determination of Nizatidine and Ranitidine in Pharmaceutical Preparations. Journal of Pharmaceutical and Biomedical Analysis, 27, 31-38. http://dx.doi.org/10.1016/S0731-7085(01)00473-3

[34] Saleh, M.M., Hashem, E.Y., Youssef, A.K. and Abdel-Kader, D.A. (2015) UV-Visible Spectrophotometric Methods 
for Direct Determination of Sulfasalazine Antibiotic Drug in Its Pharmaceutical Formulations. World Journal of Pharmacy and Pharmaceutical Sciences, 4, 205-226.

[35] Voznica, P., Havel, J. and Sommer, L. (1980) The Reactions of Gallium, Indium and Thallium with 2-(2-Pyridylazo)1-Naphthol-4-Sulphonic Acid and Their Spectrophotometric Determination. Collection of Czechoslovak Chemical Communications, 45, 54-79. http://dx.doi.org/10.1135/cccc19800054

[36] Idriss, K.A., Seleim, M.M., Saleh, M.S., Abu-Bakr, M.S. and Sedaira, H. (1988) Spectrophotometric Study of the Complexation Equilibria of Zirconium (IV) with 1-Amino-4-Hydroxyanthraquinone and the Determination of Zirconium. Analyst, 113, 1643-1647. http://dx.doi.org/10.1039/an9881301643

[37] Idriss, K.A. and Saleh, M.M. (1993) Acid-Base Characteristics of Naphthazarin and Solution Equilibria of Yttrium (III) Chelates. Analyst, 118, 223-227. http://dx.doi.org/10.1039/AN9931800223

[38] Gupta, K.K., Kaur, T. and Dadhich, E. (2013) Polarographic Study of Mixed Ligand Complexes of Pb(II) and Tl(I) with Thio Disuccinic Acid and Some Amino Acids in Aqueous Medium. Journal of Ultra Chemistry, 9, 249-256.

[39] Al-Sarawy, A.A., El-Bindary, A.A., El-Sonbati, A.Z. and Mokpel, M.M. (2006) Potentiometric and Thermodynamic Studies of Azosulfonamide Drugs. Polish Journal of Chemistry, 80, 289-295.

[40] Rahman, N., Khan, N.A. and Azmi, S.N.H. (2004) Extractive Spectrophotometric Methods for the Determination of Nifedipine in Pharmaceutical Formulations Using Bromocresol Green, Bromophenol Blue, Bromothymol Blue and Eriochrome Black T. Il Farmaco, 59, 47-54. http://dx.doi.org/10.1016/j.farmac.2003.10.001

[41] Job, P. (1928) Formation and Stability of Inorganic Complexes in Solution. Annali di Chimica, 9, 113-203.

[42] Sandell, E.B. (1959) Colorimetric Determination of Traces of Metals. 3rd Edition, Interscience Publishers, Inc., New York.

[43] Narade, S., Patil, S., Surve, S., Shete, D. and Pore, Y. (2010) Simultaneous UV Spectrophotometric Method for the Determination of Diacerein and Aceclofenac in Tablets. Journal of Pharmaceutical Science and Research, 2, 137-142.

[44] Li, R., Jiang, Z.T. and Liu, Y.H. (2008) Direct Solid-Phase Spectrophotometric Determination of Tartrazine in Soft Drinks Using $\beta$-Cyclodextrin Polymer as Support. Journal of Food and Drug Analysis, 16, 91-96. 